\title{
Wizerunek uczelni: o czym myślqa i co pisza studenci na forach internetowych
}

\begin{abstract}
Streszczenie
Wizerunek jest konstrukcją mentalną, poustaje bowiem w umysłach. Chcąc zatem zbadać wizerunek uczelni, przeanalizowano posty studentów i kandydatów do szkół wyższych występujące na popularnych forach internetowych. W wyniku przeprowadzonej obserwacji stworzono katalog determinant wizerunku, które następnie poddano szczegółowej analizie.
\end{abstract}

Słowa kluczowe: public relations, wizerunek, uczelnie, uniwersytet, fora internetowe.

\section{The image of the university: what are they thinking and what are the students writing on online forums}

\begin{abstract}
Academy's image is a mental construct because it is created in the mind. Aiming to examine the image of an academy student's and candidates posts from popular Internet forums were analyzed. As a consequence of that review, an image determinants catalogue was mapped out and these determinants were analyzed.
\end{abstract}

Keywords: image, public relations, academy, university, Internet forums.

\section{Wprowadzenie}

Poglądy, według których troska o wizerunek to tylko problem biznesu i celebrytów, należą już raczej do zamierzchłej przeszłości. Sądzę zatem, że warto zastanowić się nad tym, jaki wizerunek mają polskie uczelnie. Jest to dość istotne nie tylko dla osób tworzących strategie promocyjne czy piarowe, lecz także dla wszystkich, którzy funkcjonują w obszarze szkolnictwa wyższego.

Zanim jednak przedstawię wyniki swoich obserwacji, chciałbym poczynić kilka ustaleń terminologicznych odnoszących się do tytułu tej publikacji. Zdefiniować bowiem należy termin „wizerunek” oraz wyjaśnić, jaki związek mają z nim myślenie oraz język.

Warto w tym miejscu przypomnieć - wielokrotnie przytaczaną w literaturze sentencję Ludwiga Wittgensteina, która brzmi: „Granice mojego języka wyznaczają granice mojego świata"1. Z koncepcji tej wynika między innymi, że zachodzi ścisły

${ }^{1}$ E. Griffin, Podstawy komunikacji społecznej, tłum. O. i W. Kubińscy, M. Kacmajor, Gdańskie Wydawnictuo Psychologiczne, Gdańsk 2003, s. 181. 
związek między procesem myślenia a komunikacją werbalną. Inaczej mówiąc, nasze wypowiedzi wskazują na to, o czym myślimy i w jaki sposób postrzegamy otaczającą nas rzeczywistość. Z tym poglądem zgadzają się językoznawcy, którzy są tuórcami koncepcji językowego obrazu świata. Należy do nich między innymi Jerzy Bartmiński, który uważa, że językowy obraz świata (JOS) to zespół sądów mniej lub bardziej utrwalonych w języku, zawarty w znaczeniach wyrazów lub przez te znaczenia implikowany, który orzeka o cechach i sposobach istnienia obiektów świata pozajęzykowego². Znajomość języka daje więc nie tylko kompetencje komunikacyjne, lecz także wiąże się z naturalnym przejmowaniem określonego sposobu postrzegania świata. Język warunkuje więc nasze procesy myślowe, umożliwia nazywanie i kategoryzowanie składników otaczającej nas rzeczywistości. Umożliwia on dostrzeganie, opisywanie, a także ocenianie ułaściwości wszelkich przedmiotów i zjawisk. W tym miejscu należy też przypomnieć koncepcję symbolicznego interakcjonizmu³ ${ }^{3}$, według której, dzięki temu, że poznajemy dany język, możemy róunież poznawać świat. Można zatem powiedzieć, że świat poznajemy dzięki innym ludziom, w wyniku interakcji i komunikacji. To ludzie, z którymi mamy kontakt, prezentują określone poglądy, postawy czy opinie. My natomiast poznajemy je, a nieraz przejmujemy.

Z przytoczonego wywodu jasno wynika, że istnieje ścisła zależność między komunikacją werbalną a procesami myślowymi. Zrodzić się jednak może wątpliwość dotycząca związku wizerunku z tymi zjawiskami. Może ona powstać szczególnie u tych czytelników, którzy uważają, że wizerunek firmy lub instytucji jest tworzony przez nią samą. Tymczasem jest nieco inaczej. Znawcy przedmiotu twierdzą ${ }^{4}$, ze wizerunek to wyobrażenie, jakie ma otoczenie na temat danego podmiotu. Nie jest to obraz rzeczywisty, dokładnie nakreślony, lecz ma on charakter zmienny i zależy od subiektywnych doświadczeń, postaw i poglądów poszczególnych odbiorców. Poustaje w umysłach ludzi. Wizerunek nie jest zatem tworzony przez dany podmiot. On tylko dostarcza peunych danych, na podstawie których to otoczenie tworzy określony obraz. Wizerunek zatem ściśle zależy od tego, co myślą i mówią ludzie należący do otoczenia danej organizacji. Jest on zmysłową i intelektualną interpretacją określonego wycinka rzeczywistości. Zdaniem badaczy tej problematyki $i^{5}$ zjauisko tworzenia i poustawania wizerunku osób, instytucji itp. jest zjawiskiem naturalnym i ma uwarunkowania psychologiczne. Współczesny człowiek dąży bowiem do ukształtowania obrazu różnych podmiotów, aby ułatwić sobie w ten sposób podejmowanie określonych decyzji. Wiąże się to z potrzebą dokonywania peunej selekcji, określeniem tego, co dobre, korzystne czy wartościowe.

Podsumowując zatem poczynione rozważania, należy stuierdzić, że wizerunek uczelni tworzy jej otoczenie, w skład którego wchodzą między innymi studenci. Poustaje

\footnotetext{
2 J. Bartmiński, Językowy obraz świata, Wydawnictwo Uniwersytetu Marii Curie-Skłodouskiej, Lublin 2006, s. 58.

${ }^{3}$ E. Griffin, op. cit., s. 213.

${ }^{4}$ K. Wojcik, Public relations od A do Z, Placet, Warszawa 1997, s. 97.

${ }^{5}$ K. Bakalarski, Public relations a ksztattowanie wizerunku menedżera, Scientific Publishing Group, Gdańsk 2004, s. 173.
} 
on w wyniku wielu doświadczeń tej grupy oraz oddziaływania wielu czynników (opinii innych studentów, działalności uczelni, postaw kadry naukowo-dydaktycznej czy poglądów utrualonych w społeczeństwie mających nawet postać stereotypów). Aby zatem zbadać wizerunek uczelni, należy przeanalizować wypowiedzi studentów, którzy tworzą jedną z istotnych grup otoczenia szkół wyższych.

\section{Przedmiot i metodologia badań}

Chcąc zatem zbadać, co myślą studenci na temat uczelni, postanowiłem poddać obserwacji ich wypowiedzi na forach internetowych. Analizując te teksty, doszedłem do wniosku, że dominują w nich pewne zagadnienia, które jednocześnie stanowią istotne obszary funkcjonowania uczelni, na przykład infrastruktura, kadra dydaktyczna, zasady rekrutacji. Są to jednocześnie determinanty wizerunku szkół wyższych, dlatego zbadanie zebranego przeze mnie materiału jest istotne ze uzględu na cele tej publikacji.

Chcąc określić, jakie czynniki decydują o poustawaniu wizerunku uczelni, w czynionych tu obserwacjach uwzględniam tylko jedną grupę otoczenia - studentów. Wydaje mi się jednak, że jest to bardzo istotny interesariusz. Chcę ponadto sprawdzić, które determinanty wizerunku są wiodące, a które mają znaczenie drugorzędne. Czynione tu obserwacje nie mają jedynie charakteru statystycznego. Badam bowiem także semantykę zebranych wypowiedzi, aby ukazać postauy, emocje i poglądy.

Mam jednocześnie świadomość, że wypowiedzi pojawiające się na forach internetowych nie zausze są szczere i spontaniczne, a nawet mogą być moderowane czy uręcz nie pochodzić od osób, które się za nie podają (np. pracowników zajmujących się promocją poszczególnych szkół wyższych). Dostęp do spontanicznych i niczym nieskrępowanych wypowiedzi ustnych jest jednak niezuykle trudny.

Zebrany materiał pochodzi z ośmiu forów internetowych i dotyczy 35 uczelni, które można zaklasyfikować do pięciu następujących kategorii: uniwersytety, uczelnie politechniczne, uczelnie medyczne, uczelnie ekonomiczne i państwowe wyższe szkoły zawodowe. Zgromadzony materiał to 500 postów, z czego każde 100 postów dotyczy szkół wyższych należących do jednej z pięciu kategorii, na przykład uczelni politechnicznych czy uniwersytetów medycznych. Taki sposób gromadzenia materiału umożliwiło zastosowanie metody analizy zawartości ${ }^{6}$, która polega na obiektywnym, systematycznym i ilościouym opisie jawnej zawartości przekazu. Proces gromadzenia materiału nie miał charakteru systematycznego, co nie oznacza, że zignorowałem czynnik chronologii. Zebrany materiał został pobrany u tym samym dniu. Na potrzeby tej analizy nie jest bowiem ważne to, czy opinie dotyczące kadry, czy infrastruktury danej uczelni zmieniają się w czasie. Istotne są natomiast determinanty tworzące wizerunek, a pobranie materiału w ten sam dzień respektuje zasadę obiektywizmu.

${ }^{6}$ J. Fiske, Wprowadzenie do badań nad komunikowaniem, tłum. A. Gierczak, Astrum, Wrocław 2003, s. 149. 
Tak jak napisałem ucześniej, zajmuję się także treścią zgromadzonych postów. Badam więc warstuę leksykalną, uwzględniając semantykę występujących tam słów. Stosuję jednocześnie perspektywę semiotyczną, traktując słowo jako znak posiadający denotację i konotację?.

\section{Determinanty wizerunku polskich szkół wyższych}

Ze zgromadzonego materiału wynika, że wizerunek uczelni poustający wśród studentów zależy od 11 czynników. Są to (wymieniam w kolejności, rozpoczynając od najczęściej występującego): poziom kształcenia, kadra dydaktyczna, program studiów, studenci (ich cechy), perspektywa zatrudnienia (po ukończeniu kształcenia), obsługa studentów, rekrutacja, infrastruktura, prestiż i opinia, atmosfera (często określana jako klimat), odległość od domu. Dane procentowe podaję u tabeli 1.

Tabela 1. Determinanty wpływające na wizerunek uczelni wśród studentów

\begin{tabular}{|c|l|c|}
\hline L.p. & Determinanta wizerunku & Częstość uystępouania u \% \\
\hline 1. & poziom kształcenia & 22,20 \\
2. & kadra dydaktyczna & 18,70 \\
3. & program studiów & 13,20 \\
4. & studenci & 12,00 \\
5. & perspektyua zatrudnienia & 12,00 \\
6. & obsługa studentów & 11,25 \\
7. & rekrutacja & 10,20 \\
8. & infrastruktura & 5,70 \\
9. & prestiż, opinia & 5,70 \\
10. & atmosfera & 4,70 \\
11. & odległość od domu & 0,70 \\
\hline
\end{tabular}

Źródło: opracowanie własne.

W tym miejscu należy dodać, że niektóre z wymienionych determinant pojawiały się równocześnie $w$ jednym poście, gdyż były one odpowiedzią na zadane pytanie. Internauci chcą bowiem uzyskać informacje związane z różnymi aspektami funkcjonowania uczelni. Zadają zatem rozbudowane pytania, których egzemplifikacją może być następujący cytat:

Chciałam zapytać Was o opinie o uczelni. Jaka jest atmosfera? Panuje wyścig szczurów czy jest w miarę znośnie? Jakie jest Wasze zdanie o kadrze? Jak traktują studentów? I czy to prawda, że jest dużo egzaminów ustnych, dlatego studenci nie są przygotowani do zadań testowych, dlatego zdawalność jest niższa, niż na innych uczelniach?

${ }^{7}$ R. Grzegorczykowa, Wprowadzenie do semantyki językoznawczej, PWN, Warszawa 1990, s. 273.

${ }^{8}$ To jedno z wielu pytań skopiowanych z analizowanego forum. 
Wobec tego podawanie wartości liczbowych dotyczących frekwencji poszczególnych determinant wizerunku nie jest miarodajne.

Warto zaznaczyć, jakie czynniki przede uszystkim kształtują wizerunek szkół wyższych. Do trzech najczęściej wymienianych należą: poziom kształcenia, kadra dydaktyczna i program studiów. Sądzę, że jest to interesujący wynik, który może pobudzić do refleksji nie tylko specjalistów zajmujących się promocją uczelni, lecz także cały personel tworzący te instytucje. Poziom kształcenia, uykładowcy oraz program studiów to obszary, których jakość zależy niemal uyłącznie od kadry naukowo-dydaktycznej. To czynniki niezależne od lokalizacji uczelni czy jej potencjału. U czytelnika może zrodzić się jednak wątpliwość dotycząca pieruszej determinanty, czyli poziomu kształcenia, gdyż ten może zależeć od potencjału finansowego czy technicznego placówki. Jednakże ten czynnik to determinanta lokująca się dopiero na ósmej pozycji.

Chcę w tym miejscu podkreślić, że przeprowadzone przeze mnie obserwacje nie są reprezentatywnym badaniem, a zatem formułowane tu wnioski mają tylko charakter refleksji czy spostrzeżeń. Wiem również o tym, że studenci, oceniając poziom kształcenia, kadrę czy program studiów, stosują rozmaite kryteria.

\section{Jaki jest wizerunek uczelni?}

W tej części publikacji przedstawię wyniki analizy warstuy leksykalnej zgromadzonych postów. Celem czynionych tu rozważań nie jest statystyczne ukazanie problemu. Nie będę tu tworzył list rangowych ukazujących, czy określona determinanta wizerunku ma charakter negatywny, czy pozytywny. Zatem nie zamierzam uskazywać, czy dany czynnik (np. kadra naukowo-dydaktyczna) jest postrzegana przez studentów pozytywnie, czy negatyunie i w jakich proporcjach występują owe poglądy. Dokonam tu raczej przeglądu zebranych opinii i refleksji, chcąc ukazać różnorodne spektrum uwarunkowań upływających na poustawanie wizerunku szkół wyższych.

Studenci wypowiadający się na forach najczęściej wskazują poziom kształcenia jako kryterium oceny uczelni. Poziom kształcenia, określany też jako jakość kształcenia, często jest opisywany uprost jako wysoki lub niski. Co jest wynikiem metaforycznego pojmowania świata i rzeczywistości, o czym pisali George Lakoff i Mark Johnson? Badacze ci dowodzą, że często ujmujemy otaczające nas zjawiska w opozycji wysoki-niski. Przy czym, jeżeli coś jest uysoko, to jest to równoznaczne z osiąganiem jak najlepszego efektu, natomiast poziom najniższy ma nacechowanie przeciune. Studenci piszący o wysokim poziomie uskazują między innymi, że jest tam mega kucie. Zastosowana tu pisounia jest wiernym cytatem, który ma ukazać koloryt i styl owych wypowiedzi. Kiedy natomiast studenci odnoszą się do niskiego poziomu, używają leksemów tragedia, żenujący lub stwierdzają uprost, że dane studia niczego nie uczą, że jest tam sama teoria. Jeden z wypowiadających się negatywnie o znanej mu uczelni, stwierdził:

${ }^{9}$ G. Lakoff, M. Johnson, Metafory w naszym życiu, tłum. i ustęp T.P. Krzeszouski, PIW, Warszawa 1988, s. 145. 
To słaba uczelnia, Łatwiej wylecieć z zamkniętego tramwaju niż z tej uczelni. Często jednak w postach występują stwierdzenia ukazujące nieco pobłażliwy stosunek do omawianego tu zagadnienia. W wypowiedziach tych widoczny jest pogląd, że na studia przychodzi się tylko dla papierka. W taki nieco pogardliuy sposób określają dyplom, który można uzyskać po zakończeniu edukacji. Warto tu zurócić uwagę, że leksem papierek ma tu zdecydowanie negatywne konotacje, które wzmacnia dodatkowo zastosowanie formy deminutywnej. Wśród zgromadzonych wypowiedzi występują ponadto poglądy, według których żadna uczelnia nie uczy umiejętności, a trzeba się tego nauczyć we własnym zakresie.

O kadrze dydaktycznej móui blisko 20\% młodych internautów. Jest to istotny czynnik wpływający na sposób postrzegania szkoły wyższej przez studentów lub kandydatów. Warto w tym miejscu zurócić uwagę na nieco humorystyczne zjawisko. Otóż młodzi ludzie dokonują w swych postach zabawnego rozróżnienia. Piszą więc: tam sa fajni ludzie i kadra też. Przy czym kategoria ludzi dotyczy środowiska studenckiego, natomiast leksem kadra odnosi się do wykładouców. Opinie na temat tych ostatnich są zróżnicowane i pojawiają się oceny zarówno pozytywne, jak i negatywne ${ }^{10}$. Kiedy młodzi ludzie z aprobatą odnoszą się do kadry naukowo-dydaktycznej, piszą wóuczas:

fajni wykładowcy, nauczyciele z powołania, sympatyczni wykładowcy, pomagają nawet w prywatnych sprawach, dobra kadra, dobrze wykształcona i inspirująca kadra, super ćwiczenioucy, uspaniali wykładoucy, maksymalnie pozytywni wolnomyśliciele, świetni wykładoucy, profesjonalna kadra naukowa, on ma poczucie humoru i ogromną wiedzę; super koleś - luzak; ogólnie - mam bardzo dobrą opinię.

Bywają też wypowiedzi, w których dokonuje się podziału kadry na lepszą część i gorszą:

kadra niższa raczej fajna, wyższa czasem strzela fochy (odwrotnie proporcjonalne do «ważności» przedmiotu), ale to ogólnouczelniana tendencja; a uykładoucy.... tak jak uszędzie, są lepsi i gorsi, ci co coś wiedzą i ci, których by można wyrzucić od razu.

Opinie negatyune, podobnie jak wcześniej cytowane, są przepełnione słounictwem ekspresywnym, potocznym. Występują w nich także leksemy żargonowe lub zabarwione humorystycznie, a nawet ironicznie. Oto niektóre przykłady takich wypowiedzi:

część prowadzących to czysta kpina; część uykładoucóu każe przynosić sobie fanty (za nieobecności); niektórzy profesorowie (z całym szacunkiem) uykładają tylko dlatego, że mają poważane nazwiska i kilkadziesiąt publikacji, ale nie potrafią przekazywać wiedzy; profesorowie z zerową zdolnością przekazania wiedzy; olewatorstuo wykładowców; nieludzcy uykładowcy; uykładoucy to głównie panowie po 50, którzy nie mają pojęcia, jak wyłączyć komputer, ale zgnoić studenta to potrafią; wykładoucy nie przykładają się, nie

${ }_{10}$ Na ustępie tych rozuażań zastrzegłem, że nie analizuję tu statystycznych proporcji występujących między poszczególnymi opiniami. 
dbają o jakiekolwiek przekazanie materiału i jego pokrywanie z uykładem; tam jest takie podejście - moje uykłady są nie po to, aby je ktoś rozumiał.

Program studiów to trzeci czynnik tworzący wizerunek szkół wyższych. Tu studenci mówią, że kierunek jest fajny lub nie. Oceniając pozytyunie studia, mówią też często super kierunek. To, czy program studiów zasługuje na taką ocenę, zależy głównie od przedmiotów składających się na program kształcenia na danym kierunku. Przekonując do uyboru jakiejś uczelni, uskazują na tak zwane siatki studiów, co pokazuje bardzo racjonalne podejście do kształcenia. Analizując posty, można jednoznacznie stuierdzić, że podstawowym kryterium oceny programu danego kierunku jest obecność zajęć praktycznych. Im więcej kształcenia w formie ćuiczeń, warsztatów czy laboratoriów, tym ocena jest wyższa. Wypowiadający się na forach podają następujące argumenty, chcąc uskazać walory danego programu: to fajny program, dużo zajęć praktycznych; fajne praktyki, tam stawiają na praktykę. Krytykujący natomiast piszą między innymi:

mnóstuo nieprzydatnych, a trudnych przedmiotów; mało wiedzy praktycznej; przedmiotami najprawdopodobniej są-Budowa Arki Noego, jak ugasić Krzew Gorejący, czy zbudowanie Wieży Babel nastręcza trudności, w aspekcie budowy Śuiątyni Opaczności.

Ważnym czynnikiem determinującym wizerunek uczelni są sami studenci. Myślę, że wynik ten nie budzi zdumienia szczególnie u czytelników, którzy pracują u tych instytucjach. Duanaście procent wypowiadających się na forach internetowych pisze o społeczności akademickiej, interesując się określoną uczelnią. Najczęściej osoby studiujące określane są jako ludzie. I tak pozytywne opinie na temat ludzi zawierają następujące leksemy wartościujące: ciekawi, fajni, ogarnięci, super, w porzo, zajebiści. Wśród opinii negatywnych dominuje jeden pogląd. Wówczas młodzi ludzie o zachowaniach swoich koleżanek i kolegów piszą, że dominuje wyścig szczurów. To metaforyczne wyrażenie występuje w wielu postach. Przytaczam je nie tylko dlatego, aby ukazać emocjonalną czy potoczną leksykę, ale róunież po to, aby uskazać na dość pouszechne zjawisko ostrej rywalizacji i bezuzględnej chęci realizacji własnych celów.

Kolejnym istotnym czynnikiem kreującym wizerunek jest perspektywa zatrudnienia po ukończeniu studiów - pisze o tym 12\% młodych ludzi. Tu uypowiedzi wyraźnie są podzielone, w jednych wskazuje się na guarancje zatrudnienia, natomiast $w$ pozostałych dowodzi się, że nie ma żadnych szans na pracę po ukończeniu określonego kierunku. Do pieruszej grupy należą między innymi następujące posty:

z pracą nie jest źle, dużo firm poszukuje takich specjalistóu, daje niesamouite możliwości; ukończenie tej uczelni robi na pracodawcach wielce pozytywne wrażenie; o pracę się nie martwię, na brak pracy nie narzekam.

W wypowiedziach o przeciunym zabarwieniu wskazuje się na brak możliwości uzyskania zatrudnienia: to prosta droga ku bezrobociu; nie wiem, co potem będe robit; po tym ciężko dostać pracę; po tej uczelni cię nie zatrudnia; po takim kierunku 
tylko praca w McDonaldzie będzie. Analiza przytoczonych wypowiedzi wyraźnie uskazuje na dość pragmatyczne podejście do kształcenia, jakie prezentują młodzi ludzie. Dodać ponadto należy, że praca (zułaszcza dobra) stanowi we uspółczesnym świecie istotną wartość.

Na to, jak młodzi ludzie postrzegają szkoły wyższe, duży upłyu mają także aspekty organizacyjne i podejście do studenta. Dotyczy to przede wszystkim dziekanatów oraz innych jednostek, które zajmują się obsługą studentów, organizacją zajęć czy stypendiami. Opinie młodych ludzi mają przede wszystkim zabarwienie negatywne, toteż przedstawię głównie tego typu wypowiedzi:

straszny burdel organizacyjny, wieczny bałagan; totalny brak szacunku do studenta, często uręcz chamstwo, zułaszcza Pań u dziekanatach, bałagan; zero organizacji; plan ułożony tragicznie; rozgardiasz w dziekanatach; bałagan organizacyjny i traktowanie studentów jak intruzów; obsługa dziekanatów nadzwyczaj wredna; ile kobiet u dziekanacie, tyle odpowiedzi; ogólnie mam już dosyć tych polskich prostackich zagrywek dziekanatu; potrafią się pastuić nad studentami.

Emocjonalność przywołanych przykładów wynika zapewne ze znaczenia, jakie ma dla młodych ludzi sposób traktowania ich przez pracowników uczelni. Wyraźnie widać, że oczekują podmiotowego traktowania, chcą mieć poczucie, że są ważni dla instytucji, w której się kształcą. W postach tych obecne jest słownictwo typowe dla języka studenckiego - totalny (brak), zero (organizacji), ogólnie (mam już dosyć). Leksemy ogólnie, totalny, zero bardzo często pojawiają się u słowniku studenckim, co uskazuje na charakterystyczne cechy komunikacji werbalnej interesującej mnie grupy społecznej.

Dziesięć procent wypowiadających się na forach jako ważny czynnik wymienia warunki rekrutacji i poziom trudności występujący podczas naboru. Tu młodzi ludzie raczej nie oceniają, tylko często o tym piszą, co zdecydowanie wskazuje, że jest to dla nich ważny element. Z zebranych wypowiedzi można jednak wysnuć uniosek, że te uczelnie, do których trudniej się dostać, są oceniane przez młodzież lepiej. Piszą między innymi: jest wielu chętnych na ten kierunek, niełatwo się tam dostać.

Takie samo znaczenie dla młodzieży mają infrastruktura i prestiż uczelni. W obu przypadkach pisało o tym ponad 5\% forumowiczów. Jeżeli piszą o infrastrukturze, to tylko w ujęciu pozytyunym. Chwalą wówczas uyposażenie budynków, standard akademików czy jakość i dostępność bibliotek. Kiedy natomiast odnoszą się do renomy danej szkoły wyższej, odwołują się do rankingów: w tym roku zajęli pierwsze miejsce w rankingu „Newsweeka”; weźcie dajcie w ogóle spokój, zauważcie, że te rankingi wcale się nie pokrywaja z praktyka. Z przytoczonych wypowiedzi wynika, że opinie mają charakter negatyuny i pozytyuny. Ważne być może w tym miejscu jest co innego, a mianowicie to, że rankingi są jednak czynnikiem opiniotwórczym, a zatem należy je uwzględniać. Kiedy młodzi ludzie odnoszą się do prestiżu uczelni, używają następujących leksemów: opinia, popularność, poważanie, renoma, sława (dobra lub zła). 
Niespełna 5\% postów zawierało refleksje dotyczące atmosfery panującej w omawianej uczelni. Jeżeli młodzi ludzie poruszają to zagadnienie, to czynią to uyłącznie w aspekcie pozytywnym. Piszą między innymi:

ta uczelnia ma suój klimat; tu studiują ludzie z pasją i ambicją; jest cudouna atmosfera; to niesamowity klimat; bardzo fajna uczelnia, ta uczelnia ma klimat :), nawet te stare budynki urzekają jakąś dostojnością...; uczelnia ma klimat; moja uczelnia, mój uniwersytet, kuźnia wiedzy, praktyki i ... życia dla wielu pokoleń; royal-atmosfera.

Myślę, że warto pochylić się nad tymi wypowiedziami i dostrzec ich głęboki sens. Otóż jest część środowiska studenckiego, która idąc na studia, poszukuje szczególnych doznań. Sądzę, że warto wziąć pod uwagę ten aspekt, tworząc strategię wizerunkową szkół wyższych.

Nieco ponad 0,5\% wypowiedzi odnosi się do lokalizacji uczelni, a w szczególności do jej odległości od miejsca zamieszkania. Wydawać by się mogło, że młodzi ludzie dążą do wygody i ułatwiania sobie życia, a zatem bliskość powinna stanowić dla nich ważne kryterium. Tymczasem tak nie jest. Przykładem jest wypowiedź jednego ze studentów, który stwierdza, że chociaż jego uczelnia znajduje się w mieście, które jest odległe od jego rodzinnej miejscowości, to i tak jest bardzo zadowolony z dokonanego wyboru.

\section{Podsumowanie}

Podstawowym celem przeprowadzonej tu analizy było stworzenie katalogu determinant decydujących o poustawaniu wizerunku szkół wyższych. Ponadto chciałem przyjrzeć się specyfice ouych czynników, aby osoby pracujące w tych instytucjach lub odpowiedzialne za ich strategie komunikacyjne mogły być bardziej skuteczne.

Pewnym zaskoczeniem dla mnie był fakt, że pięć najbardziej znaczących czynników wpływających na poustawanie wizerunku szkół wyższych nie ma związku z potencjałem finansowym lub promocyjnym tych instytucji. Do pięciu najistotniejszych determinant należą bowiem: poziom kształcenia, kadra naukowo-dydaktyczna, program studiów, studenci i perspektywy zatrudnienia po ukończeniu kształcenia. Są to elementy niemal wyłącznie zależne od uykładowców. Z pewnością mają oni niemal całkowity upływ na poziom kształcenia i program studiów. Oni sami są bardzo ważni dla młodych ludzi, a więc ich postawa istotnie wpływa na to, co myślą studenci. Pośrednio związek z programem studiów i poziomem kształcenia ma ostatni z uymienionych tu czynników, czyli perspektywy zatrudnienia. Kadra ma róunież pośredni upływ na to, jacy są sami studenci, gdyż to wykładowcy zajmują się rekrutacją oraz kształtują środowisko akademickie. Zatem to, jaki wizerunek mają szkoły wyższe, w dużym stopniu zależy od kadry naukowo-dydaktycznej. Warto jednocześnie zauważyć, że postawa młodzieży wobec kształcenia na poziomie akademickim ma charakter racjonalny i pragmatyczny.

Obserwacja warstuy leksykalnej zgromadzonych postów miała ukazać poglądy młodzieży. Jednakże jej ważnym celem było dostarczenie materiału osobom 
odpowiadającym za promocję i wizerunek szkół wyższych. Chciałem wskazać istotne dla młodych ludzi wartości oraz słownictuo, jakim się posługuję. Tak zgromadzony materiał językowy może bowiem być uykorzystany w rozmaitych tekstach promocyjnych. W wypowiedziach młodzieży występuje kilka wyraźnych tendencji. Posługują się oni słounictwem potocznym, zabaruionym emocjonalnie, żargonowym, modnym oraz nieco uulgarnym. W tych wypowiedziach nierzadko występują także ironia i humor.

\section{Bibliografia}

Bakalarski K., Public relations a ksztattowanie wizerunku menedżera, Scientific Publishing Group, Gdańsk 2004.

Bartmiński J., Językowy obraz świata, Wydawnictwo Uniwersytetu Marii Curie-Skłodouskiej, Lublin 2006.

Fiske J., Wprowadzenie do badań nad komunikowaniem, tłum. A. Gierczak, Astrum, Wrocław 2003.

Griffin E., Podstawy komunikacji społecznej, tłum. O. i W. Kubińscy, M. Kacmajor, Gdańskie Wydawnictuo Psychologiczne, Gdańsk 2003.

Grzegorczykowa R., Wprowadzenie do semantyki językoznawczej, PWN, Warszawa 1990. Lakoff G., Johnson M., Metafory w naszym życiu, tłum. i ustęp T.P. Krzeszouski, PIW, Warszawa 1988.

Wojcik K., Public relations od A do Z, Placet, Warszawa 1997.

\section{Fora internetowe \\ wuw.uizaz.pl wuw.uczelnie.info.pl wuw.forum.studia.net wuw.goldenline.pl uwu.forum.biolog.pl wuw.money.pl wuw.gazeta.pl wuw.biotechnolog.pl}

